\title{
A SOCIOLOGY OF THE SOVIET UNION
}




\section{A Sociology of the Soviet Union}

Gary Littlejohn

Macmillan Education 
ISBN 978-0-333-29427-7 ISBN 978-1-349-17358-7 (eBook)

DOI 10.1007/978-1-349-17358-7

(C) Gary Littlejohn 1984

Softcover reprint of the hardcover 1st edition 1984

All rights reserved. For information, write:

St. Martin's Press, Inc., 175 Fifth Avenue, New York, NY 10010

Published in the United Kingdom by The Macmillan Press Ltd First published in the United States of America in 1984

ISBN 978-0-312-74077-1

\section{Library of Congress Cataloging in Publication Data}

Littlejohn, Gary.

A sociology of the Soviet Union.

Bibliography: p.

Includes index.

1. Soviet Union-Social conditions. 2. Soviet Union-

Economic conditions. 3. Social classes-Soviet Union-

History -20 th century. 4. Socialism-Soviet Union-History

-20 th century. I. Title.

HN523.L49 $1984 \quad 306^{\prime} .0947$

$83-19111$

ISBN 978-0-312-74077-1 


\section{Contents}

Acknowledgements ix

Introduction $\quad 1$

1 The Class Structure: Stratification or Relations of Production? 7

Introduction $\quad 7$

Stratification: Theory and Evidence $\quad 9$

Weberian Stratification $\quad 10$

Marx's Theory of Classes under Capitalism $\quad 17$

Problems with Marx's Analysis 23

Implications for a Theory of Class 28

'Possession' of the Means of Production 33

Class Relations and the Division of Labour
under Socialism

Conclusion $\quad 39$

2 Hammer and Sickle: Problems of a Worker-

Peasant Alliance $\quad 42$

Introduction 42

State-Peasant Relations before the

New Economic Policy 44

The black redivision $\quad 44$

The Kombedy 45

The results of the Givil War on agriculture $\quad 50$

Conclusions on the pre-NEP period 52

State Policy on Commodity Relations with the

Peasantry during the New Economic Policy 54 
Attempts at the socialisation of agriculture 1918-21 55

The land organisation programme $\quad 57$

The scissors crisis $\quad 58$

Agricultural marketing and the rural class structure 61

The conceptualisation of socialist transformation

under NEP

The formation of collective farms in the 1920s 68

Political work in the countryside $\quad 71$

The implementation of national economic policy $\quad 77$

The Crisis and Demise of NEP $\quad 83$

Conclusion $\quad 89$

3 Economic Units and Economic Calculation:

The Basis of Production Relations 100

Introduction $\quad 100$

$\begin{array}{ll}\text { Agriculture } & 103\end{array}$

The kolkhozy 104

The convergence of kolkhozy and sovkhozy $\quad 107$

Personal plots 108

Retail trade $\quad 110$

Overview of agriculture $\quad 110$

Industry 111

State enterprises $\quad 111$

Production associations and Ministries $\quad 116$

The regulation of plan implementation $\quad 122$

Economic calculation and central planning $\quad 127$

The 1979 reform 131

Conclusion 135

4 Law, State and Politics 140

Introduction 140

Law 141

Law and socialism 141

Legal regulation of the Soviet economy $\quad 145$

State and Politics 147

Politics and the relations of production $\quad 150$

Totalitarianism 150

Elite theory 152 Hough's approach to Soviet politics:
institutional pluralism 
An alternative approach to Soviet politics:

arenas of struggle

State and party agencies and economic policy

Conclusion

5 Welfare and Consumption:

Relations of Distribution

Introduction

Housing

Political aspects of housing provision

The social distribution of housing

Effects on the distribution of income

Health

Health politics: administration, finance

and policy

Health planning

Health finance

Soviet health policy

200

Health and democracy

201

Access to health care

203

Soviet health: conclusion

205

Social Security

205

Social security administration, finance and policy

Social security policy

The effects of social security

Conclusion: An Assessment of Welfare and Consumption

6 The Analysis of the Class Structure of the Soviet Union

Introduction

Occupational Structure and Class Structure

The Soviet Occupational Structure: Lane's Analysis

The Occupational Structure of Soviet Women

Social Policy and Female Waged Labour 240

Collective Farm Workers

The 'Intelligentsia'

Education 
viii Contents

The Soviet Occupational Structure, Collective Agents and Class Relations

Industrial workers

254

Collective farm workers

256

Non-manual occupations

256

The Distribution of Wages and Income Levels

261

Conclusion: The Presence of Class Relations

in the Soviet Union

264

Glossary

275

Chronology

277

Bibliography

278

Index

284 


\section{Acknowledgements}

My first thanks must go to Hillel Ticktin, who supervised the thesis on which this book is based. I should also like to thank Stephen Feuchtwang, Barry Hindess, Paul Hirst, Professor Marie Lavigne and Professor Pierre Lavigne, all of whom read parts of my thesis and whose comments improved it. None of them is responsible for the remaining deficiencies, or for the views expressed here.

G.L. 